\title{
Uneven Access and Underuse of Ecological Amenities in Urban Parks of the Río Piedras Watershed
}

\author{
Luis E. Santiago $^{1}$, Julio C. Verdejo Ortiz $^{1}$, Raul Santiago-Bartolomei $^{1}$, Elvia J. Melendez-Ackerman $^{1}$ and Diana C. Garcia-Montiel $^{2}$
}

\begin{abstract}
The association between consumption of ecological amenities in a park setting and improved physical and mental health substantiates the need for improved accessibility to green areas in lower-income neighborhoods. We measured green area accessibility, considering income variation, and park use in a densely populated tropical urban watershed. Park use was explored with 442 in-person interviews, and U.S. Census and Puerto Rico Commonwealth data were used to measure accessibility. Nearly $20 \%$ of residents earning $\leq \$ 15,000$ lived within park service areas with the highest crime incidence in the region, whereas $90 \%$ of those earning $>\$ 75,000$ lived within park service areas with lower crime rates. Innovative nonexclusionary activities such as growing vegetable gardens are needed to attract lower-income residents and increase their sense of safety in urban parks.
\end{abstract}

Key Words: accessibility; ecological amenities; Puerto Rico; Rio Piedras watershed; urban parks

\section{INTRODUCTION}

For an urban watershed like that of the Río Piedras in San Juan, Puerto Rico, green areas can provide ecological amenities that range from the reduction of runoff that can cause flooding and deteriorating water quality in low-lying areas to various benefits for resident well-being and long-term sustainability (Chiesura 2004, Farber et al. 2006, Schipperijn et al. 2010). Green spaces also add value to residential sales prices (Jim and Chen 2006, Troy and Grove 2008, Saphores and Li 2012). However, public sector measures to conserve green areas in urban environments have often been insufficient, contributing to the loss and continuous degradation of green space in urban areas, often reducing the availability of urban parks (Heynen et al. 2006, Tzoulas et al. 2007). At the same time, previous works have underlined the process where poverty or other social factors such as race create areas within the city where lack of access to natural resources is prevalent (Logan 1978, Perkins et al. 2004, Heynen 2006, Peterson and Krivo 2010). The aims of this study are to explore whether watershed residents associate urban parks with green areas and the consumption of ecological amenities, and to document variations in accessibility as a result of income disparities across the watershed.

\section{Association between watershed public green areas and neighborhood parks}

Because urban neighborhood parks often provide urban residents some of the closest locations to consume certain ecological amenities (Kaplan and Talbot 1988, Jim and Shan 2013), the extent to which residents associate neighborhood parks with green areas constitutes a key component in this research. Government officials, particularly urban planners and real estate developers, have often conceived urban parks as public spaces where residents can recreate conducting passive and exerciserelated recreation activities, among others (Budruk et al. 2009). As a result, common features of urban parks in the Río Piedras watershed considered for this study include basketball courts, baseball parks, and jogging tracks, where physical activities are conducted, and sitting and picnic areas, where passive recreation and social gatherings might occur.
Proximity to public green areas and neighborhood parks

A second key component of this research is the residents' level of proximity to green areas and neighborhood parks in the Río Piedras watershed, considering distance to parks and green area density measures. There is scant literature on this topic in the Caribbean region. In the United States, Nicholls (2001) examined accessibility to 29 municipal parks in Bryan, Texas, considering the population within a road network service area in a Euclidean distance buffer of $800 \mathrm{~m}$ around each facility. The author found that accessibility in terms of distance was poor, with $<40 \%$ of the population having access to open spaces, and $12 \%$ to a park.

European studies on urban green area accessibility show variation in compliance to existing regulations. Barbosa et al. (2007) examined access to green spaces in Sheffield, UK. They measured the distance along the road network from 179,844 residences to the nearest entrance to facilities with public green areas and examined the distance between 87 municipal parks and 10,000 households using network distance methodology. Only $36.5 \%$ of households were accessible, according to UK government guidelines, whereas $95.6 \%$ were in agreement with European Environment Agency recommendations. Comber et al. (2008) examined whether density guidelines in the city of Leicester, UK, were met. Using network analysis of distance from 890 output areas to 52 diverse green spaces, they found that Leicester met guidelines for green space provision, providing 3.5 ha per 1,000 inhabitants, a figure higher than the minimum 2 ha per 1,000 inhabitants required by established municipal or state guidelines.

\section{Social factors hindering accessibility to public green areas and neighborhood parks}

Accessibility to urban parks by various segments of the population may also be influenced by what is considered legitimate behavior in public areas, existing regulations concerning such behavior, and enforcement levels (Hartley 1992, Mitchell 1995, Berney 2010). If residents feel their neighborhood park is unsafe because of the occurrence of behavior that is considered illegitimate, they may not consider it as an option when selecting places to consume ecological amenities. Neglect of park vegetation and facilities may also act as a deterrent for potential visitors.

\footnotetext{
${ }^{1}$ University of Puerto Rico at Río Piedras, ${ }^{2}$ Institute for Tropical Ecosystem Studies, University of Puerto Rico

* The first and second authors contributed equally to this manuscript.
} 
Some studies confirm that urban parks are perceived as dangerous by certain users, including reports of intimidation from groups of young people, and even physical and sexual assault (MacNaghten and Urry 2000, Ward Thompson et al. 2004). In a recent study conducted in Cape Town, South Africa (George 2010), perceptions that a park was unsafe tended to increase with respondent age. In spite of a high reported crime rate at the park, domestic visitors indicated that they would revisit and recommend the park to others. George (2010) thinks this could be indicative of a host population well adjusted to living in a society with a high crime rate.

Findings are mixed on how a park's green areas are related to a sense of safety. It seems that the effect of tree density on safety depends on context. Kuo et al. (1998) found that tree density and grass maintenance increased both preference and a sense of safety for a sample of low-income residents in Chicago, Illinois, USA. Assessing the effects of tree cover on crime in Portland, Oregon, USA, Donovan and Prestemon (2012) found that trees, as an attribute of a well-kept neighborhood, might give criminals the impression of being observed by authority, thus deterring crime occurrence. In Baltimore, Maryland, USA, Troy et al. (2012) found an inverse relationship between crime rates and tree canopy cover. In contextualizing the surroundings of tree coverage or other green areas, they believed that vegetation could be perceived as more threatening when unfavorable socioeconomic characteristics are prevalent. Levels of biodiversity apparently hold little interest for users (Sanesi et al. 2006, Cohen et al. 2010).

\section{Recreation and consumption of ecological amenities in green areas and neighborhood parks}

Health benefits of nature-based recreation experiences in urban park settings, such as walking and jogging, have been established in the literature (Bedimo-Rung et al. 2005, Maller et al. 2006, Boone et al. 2009). Regular physical activity has been shown to reduce morbidity and mortality by decreasing heart disease, diabetes, high blood pressure, colon cancer, feelings of depression and anxiety, and weight (U.S. Department of Health and Human Services 1996). In addition, urban green spaces, often present in urban parks, may help decrease levels of mental stress related to urban living, modern work practices, and hazardous environments (Tabbush and O'Brien 2003).

Residents' motives for visiting urban parks may help identify patterns of consumption of ecological amenities. Two studies on European parks conducted by Chiesura (2004) and Schipperijn et al. (2010) documented the main reasons for park visitation. Both of these studies, conducted in The Netherlands and Denmark, respectively, show strong ties between recreation activities and natural area settings. The majority (54\%) of Dutch respondents indicated that they visit parks to listen to and observe nature, and $45 \%$ of the Danish respondents considered observing flora and fauna part of their experience in green areas. Physical activity was also important in the Danish case, where $55 \%$ of respondents mentioned visiting green spaces to keep in shape. This figure was significantly lower $(11 \%)$ in the Dutch case.

Our research aims to identify green area accessibility, considering income variation, and consumption patterns of ecological amenities in a densely populated tropical urban watershed. We asked: Which ecological amenities do area residents consume? Does resident accessibility to watershed green areas increase with income?

\section{METHODS}

The watershed was the unifying unit of analysis for our urban long-term research area. The Río Piedras watershed (RPW) covers most of the Municipality of San Juan, the capital of the Commonwealth of Puerto Rico. Serving a population of 381,931 (U.S. Census Bureau 2010), San Juan has listed 225 facilities, including parks for passive and active sports recreation, plazas (town squares), stadiums, and green vacant lots that are used by some communities for recreation (Municipality of San Juan Territorial Planning and Ordinance Office 2012, unpublished data). Our analysis was conducted using both primary and secondary data sources. The relationship between green spaces, public parks, and recreation was explored with in-person interviews. Accessibility to green spaces in the watershed was analyzed using aggregate U.S. Census and Puerto Rico Commonwealth data.

A stratified sampling design was used to conduct in-person interviews at six sites within the RPW. Within the watershed, six sampling sites consisting of a $1 \mathrm{~km}$ radius were selected to reflect variations in pre-determined physical site and socioeconomic characteristics. The watershed was divided into three areas, upper, middle, and lower, and each of those areas contained two sampling sites. The upper portion of the watershed has a lower population density with larger lot sizes. The middle and lower portions of the watershed are more heavily urbanized, with smaller lot sizes, on average, and a higher presence of built areas. Our sample was stratified by randomly selecting streets for conducting surveys within each of the six sites. The availability component of our sampling strategy consisted of including only residences or apartments located in selected streets within the sampling circles where a resident was available and willing to participate in our survey. Data from 442 households were collected between January and October 2011.

The questionnaire was exploratory in nature and identified residents' perceptions and attitudes toward green areas, particularly trees, location and use of neighborhood parks, and patterns of use by residents. The survey included both open-ended and choice questions on natural resource perceptions and activities conducted in neighborhood parks. A majority of green area recreation questions were open-ended to minimize response bias. Respondents were asked whether there was a public park nearby, whether they felt safe, and if not, what would make them feel safer. Open-ended questions on problems and benefits associated with public park areas were also included. Respondents were also asked to mention which activities they would conduct in their closest recreation facility to identify consumption patterns of ecological amenities. Coding categories were then developed to classify and group all of the obtained responses according to different types of activities. The resulting nonmutually exclusive categories were: social, natural, exercise, consumption, and digital.

Social activities are those dependent on the presence of others and can occur in a variety of settings, natural and built. Examples of respondent answers to these categories include family gatherings, community gatherings, recreation centered on children's activities, group classes or lessons, team exercise or sports, music concerts, and artisan fairs. 
Table 1. Accessibility to urban parks by income group.

\begin{tabular}{lcccc}
\hline \hline Income group & Population & $\begin{array}{c}\text { Number of parks and } \\
\text { recreational facilities }\end{array}$ & $\begin{array}{c}\text { Population in service } \\
\text { areas }\end{array}$ & $\begin{array}{c}\text { Percentage of population } \\
\text { in service areas }\end{array}$ \\
\hline$\$ 0-\$ 14,999$ & 14,176 & 6 & 2506 & $18 \%$ \\
$\$ 15,000-\$ 29,999$ & 48,817 & 24 & 30,173 & $62 \%$ \\
$\$ 30,000-\$ 44,999$ & 50,818 & 22 & 17,839 & $35 \%$ \\
$\$ 45,000-\$ 59,999$ & 27,186 & 14 & 13,909 & $51 \%$ \\
$\$ 60,000-\$ 74,999$ & 21,554 & 27 & 11,525 & $53 \%$ \\
$\$ 75,000+$ & 5442 & 7 & 4959 & $91 \%$ \\
Total & 167,993 & 100 & 80,911 & $48 \%$ \\
\hline
\end{tabular}

Consumption of ecological amenities is most closely related to nature-based activities because it must occur in a green area or body of water. The presence of a natural area is necessary to conduct the recreation activity. Examples of nature-based activities in our sample include gardening, small-scale residential agriculture, beach recreation (swimming, bathing, tanning, etc.), contemplation of nature, meditation in green areas, fishing, and camping. Goods consumption-based recreation did not include ecological amenities. The most frequently mentioned goods consumption recreation experiences include eating, drinking, and shopping.

Exercise recreation is rigorous physical activity and may be conducted by the respondent individually or in the company of others. Although many respondents did not specify a particular type of exercise, several mentioned playing sports, swimming, skating, karate, racquetball, horseback riding, dance lessons, golf, and bike riding.

Digital-based recreation is a term used to describe a recreation experience in which digital data or information are central to the activity. Examples of digital recreation mentioned by our users include watching television, watching movies, listening to music, communicating via social networks, and taking photographs.

A recreation response may be classified into one or more of these categories. For instance, a dance lesson contains both a socially centered component, since it is conducted in a group setting, and an exercise-based component, requiring a rigorous amount of physical activity.

To estimate the residents' accessibility to green areas, we examined socioeconomic and demographic characteristics of the RPW population within a walkable distance buffer to green and public recreational areas. The buffer extended to $500 \mathrm{~m}$ using the road network. Geocoded crime report data for each area were used to determine the safety of each space, which is another indicator of accessibility.

Using GIS techniques, we generated a service area for each of the 49 parks or public spaces. This service area represents $500-\mathrm{m}$ coverage using the road networks as a guide, instead of circular as the crow flies, from each point. The service areas were used to determine the population served using georeferenced 2010 census data on Tiger line shapefile geographies of census tracts and blocks. The remaining population of the census tract outside each service area was identified as one with a lack of access to a park or public space. For green area coverage of each census tract, a 0.3-m resolution aerial image, a product of remote sensing, was used. Residential lot green area coverage was obtained from land plot data provided by the Center for Municipal Revenue (CRIM). To determine the social characteristics of the population, data from the 2006-2010 5-yr estimate reports of the Puerto Rico Community Survey were used (U.S. Census Bureau 2010). Population counts within census tracts and blocks were obtained from the 2010 decennial census. Type 1 crime statistics for 2011, which include homicide, rape, robbery, and aggravated assault, were obtained from the Puerto Rico Police Department San Juan Region Commandants office (Puerto Rico Police Department 2012, unpublished data).

\section{RESULTS AND DISCUSSION}

\section{Physical and social factors hindering resident accessibility to green areas as a function of income and incidence of crime}

Results from the RPW indicate that $48 \%$ of residents in the study area lived within walking distance of an urban park. If income level is considered, only $18 \%$ of residents earning $\leq \$ 15,000$ lived within service areas (Table 1). The second lowest income group, those earning $\$ 15,000-\$ 29,999$, exhibited higher access than most income groups. The smallest population group in the watershed was reported in the highest income category, and $91 \%$ of the population lived within service areas. Served by seven facilities and showing an overlap of five service areas, the highest earners were concentrated in just one area of the watershed (Fig. 1). Access for this high-income group is greater in part because it occupies a smaller surface area. The map also shows that highincome groups are located mainly in the central region of the watershed; most of these residents live in gated neighborhoods and have access to gated private common areas. It would seem that access increases for higher-income groups as a result the creation of gated neighborhoods, by which several public spaces became restricted-access common areas. Resident associations, as well as central and local government entities, often maintain these areas.

We examined the incidence of crime compared to median family income in park service areas (Fig. 2). A majority of criminal incidents were reported in the lower (northern) and central regions of the watershed. The lowest-income families were also located in the lower region of the watershed, coinciding with areas of high incidence of crime. In lower-income areas of the watershed, $76.5 \%$ of criminal incidents occurred within $500 \mathrm{~m}$ of a park (Table 2). 
For income groups earning $<\$ 75,000,>50 \%$ of incidents also occurred within close proximity to a park. Few incidents were reported in the upper (southernmost) region of watershed. This is partly because of the availability of fewer and underused recreation facilities, as well as a lower population density in this area. We think that the distribution of criminal activity observed in the watershed might be dependent on unstudied factors such as the geographic allocation and time cycle of specific types of illegal activity, which would not be reflected in Type I crime statistics.

Fig. 1. Median family income by census tract.

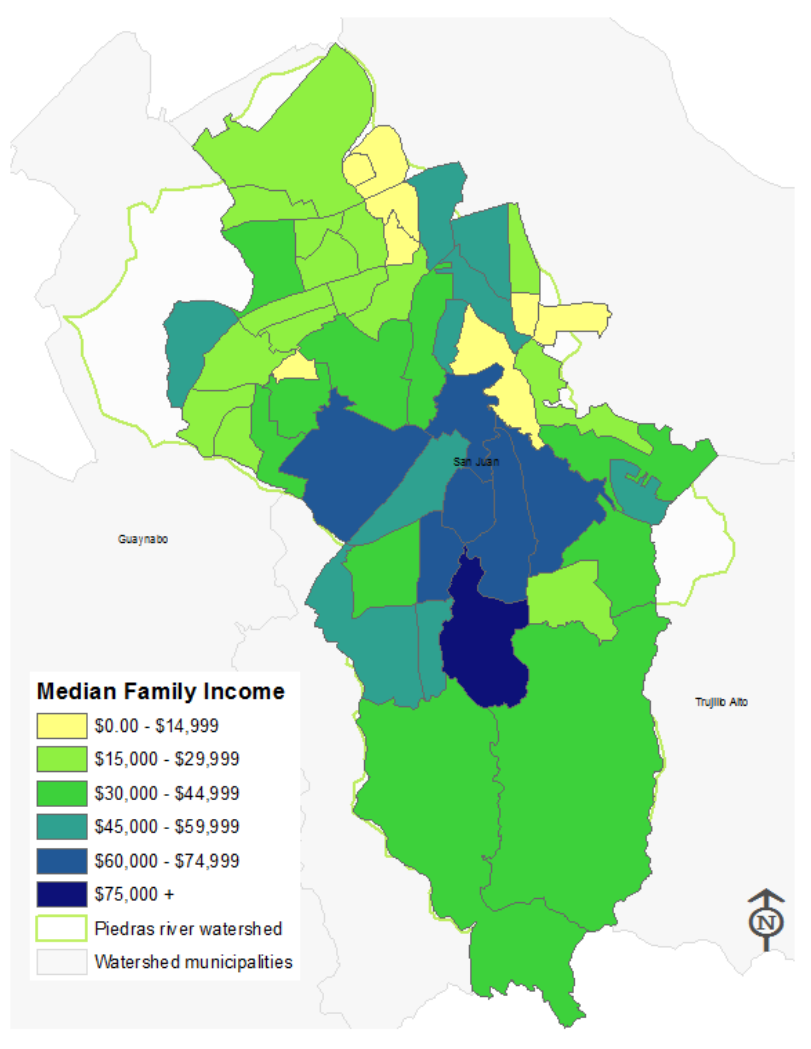

The highest-income families seem to be concentrated in the central region, where several gated communities were built in the 1990s. The use of common areas in these gated communities is usually highly regulated, and private resources are dedicated to enforcement. Reported criminal activity is therefore lower than in public parks. Safety conditions provide greater access for gated community residents, who feel that their parks and common areas do not harbor activities that might discourage their use. Homeowners associations often regulate access for those who do not reside in gated communities. A recent case ruling regarding religious groups' rights to enter gated communities has increased the permeability of gated boundaries, but those who wish to enter these neighborhoods would still have to identify themselves at the gates (Watchtower Bible Tract Society of New York, Inc., et al. v. Municipality of Santa Isabel et. al., 2012).
Fig. 2. Location of type I crime incidents by census tract in 2011.

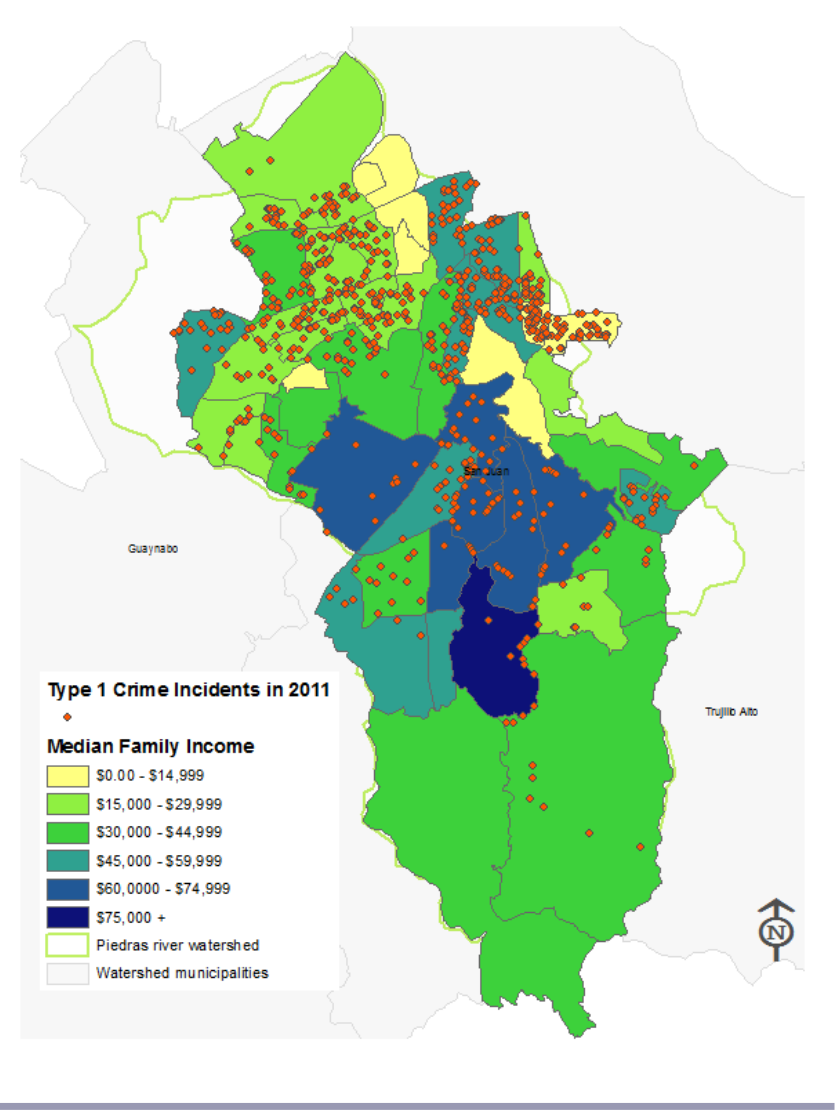

Safety perception as a key factor hindering accessibility to public green areas and neighborhood parks

We also examined resident perceptions of safety in public parks and green areas to understand the extent to which these views were hindering accessibility. We found that $60 \%$ of respondents indicated feeling safe in their neighborhood park. The remaining $40 \%$ who felt unsafe were asked to provide solutions that would help increase the feeling of safety when visiting these urban parks. The majority of respondents who indicated not feeling safe did not specify measures that would increase their sense of safety, and only $23 \%$ who did not feel safe provided suggestions.

The solutions proposed by the 61 residents were coded and classified into the following broad categories: law enforcement, physical infrastructure, institutional, and behavioral. Even though law enforcement can be classified as an institutional measure, we separated it into its own category because of the high frequency with which it was mentioned.

Physical infrastructure solutions to increase residents' sense of safety included better lighting, installing or improving controlled access facilities, reinforcing entrance locks, maintaining turf, and installing fences. Vegetation-related safety improvements were among the least frequently mentioned solutions, with only three 
Table 2. Amount of crime in service areas by income group.

\begin{tabular}{lccc}
\hline \hline Income group & Included census tracts & Included service areas & $\begin{array}{c}\text { Percentage of crime in service } \\
\text { areas }\end{array}$ \\
\hline$\$ 0-\$ 14,999$ & 115 & 88 & $76.5 \%$ \\
$\$ 15,000-\$ 29,999$ & 276 & 169 & $61.2 \%$ \\
$\$ 30,000-\$ 44,999$ & 136 & 82 & $60.3 \%$ \\
$\$ 45,000-\$ 59,999$ & 234 & 133 & $56.8 \%$ \\
$\$ 60,000-\$ 74,999$ & 86 & 61 & $70.9 \%$ \\
$\$ 75,000+$ & 9 & 2 & $22.2 \%$ \\
Total & 856 & 535 & $63 \%$ \\
\hline
\end{tabular}

residents identifying turf maintenance as a problem associated with their neighborhood park. All but one of the physical recommendations were associated with groups and activities that residents considered should be excluded from the park. Behavioral improvements were similarly actions taken by residents to exclude themselves from the park, such as not leaving the house and not entering the park.

Enforcement of current applicable regulations, or control of actions considered illegitimate by residents, was the most commonly suggested intervention, mentioned by 37 residents, or $61 \%$ of the population who indicated not feeling safe in their neighborhood park and who recommended safety improvements. The socioeconomic profiles of those respondents was generally representative of the whole population, although the average income was slightly lower than the whole-sample mean $(\$ 27,687$ vs. a mean of $\$ 32,917$ ). A look at the distribution of responses by watershed location shows that the majority of requests for law enforcement solutions occurred in the middle and lower watershed locations, with the exception of La Sierra. We think that the occurrence of residents who live in gated communities can partially explain the lower numbers who suggested law enforcement in La Sierra, a middle-watershed location containing several gated neighborhoods. In this case, the neighborhood parks are located within the gated locations and are patrolled by private law enforcement. The remaining three middle and lower watershed locations, i.e., Ave. Central, Puerto Nuevo, and San Patricio, representing middle and lower income levels, suggested law enforcement in higher numbers than did the upper watershed locations.

Institutional improvements, which were mentioned less frequently, included nonexclusionary solutions such as the implementation of community education programs, improving economic conditions to prevent crime, and conducting activities at night to diminish delinquency.

\section{Association between watershed public green area benefits and problems and neighborhood parks}

Interviews revealed that $83 \%$ of surveyed watershed residents reported living close to a neighborhood park. A majority of residents $(78 \%)$ also indicated that their neighborhood parks provided benefits, whereas only $10 \%$ identified problems. When watershed residents were asked to identify the benefits and problems associated with their neighborhood parks, the majority of responses were not associated with green areas. When asked about benefits, each respondent was allowed to provide up to three answers. We obtained a total of 442 responses indicating benefits. Only 20 , or $4.4 \%$, of those responses were directly related to green areas. These answers included the mention or provision of the following services: trees, shade, green areas, forests, vegetable gardens, natural resources, flora and fauna, and bird watching. Resident responses show a low association between the benefits provided by urban parks and the existence of green areas.

When asked to mention problems with neighborhood parks, each respondent was also allowed to provide up to three answers. Residents provided a total of 47 responses. Only 9 of the 47 responses, or $19 \%$, could be associated with green areas or vegetation. Eight of those nine responses referred to a lack of landscape maintenance. As in the case of benefits of urban parks, there is a low association between problems reported by residents in urban parks and green areas, but in this case, there is consistency in the identification of the problem, landscape maintenance.

\section{Consumption of ecological amenities in green areas and neighborhood parks}

A majority of reported park activities could be conducted without consumption of ecological amenities in a park setting. Exerciserelated recreation activities were the most frequent, mentioned by $45 \%$ of respondents. In second place, nearly $25 \%$ of respondents indicated participating in activities with a predominant social component. Goods consumption-related activities were less prevalent $(11 \%)$, as were technology $(6 \%)$, and passive recreation $(6 \%)$. Some of the least frequently mentioned activities were those requiring consumption of ecological amenities in a park setting $(6 \%)$. Only $10 \%$ of respondents indicated that that they did not participate in any activity in a park setting.

The socio-demographic profile of respondents who show greater affinity for consumption of ecological amenities in a park setting does not exhibit characteristics significantly different from that of the average respondent in the watershed. Average income seems to be slightly higher than the overall mean, and a higher proportion of men participate in nature-related recreation, when compared to the average for the watershed. However, women constitute $>50 \%$ of respondents engaged in a natural-area-related activity.

The one pattern that seems quite strong with consumption of ecological amenities in a park setting is the proportion of residents who grow food in their backyard. Even though backyards represent a large component of available green area in the watershed, unlike urban parks, they are private and highly accessible only to household residents. We found that $73 \%$ of 
residents who conduct nature-related activities grow food in their backyard. An in-depth exploration of the relationship between agriculture and consumption of ecological amenities in a park setting merits further research.

The location of respondents engaged in consumption of ecological amenities in a park setting seems to follow a pattern indicative of higher than average green area availability at each site. We found that $45 \%$ of respondents engaged in activities dependent on natural settings come from one of the six watershed sampling sites: Cupey. This sampling site is the least dense area in the watershed in terms of population, with the highest abundance of green areas.

\section{POLICY IMPLICATIONS}

Tough-on-crime policies implemented in the last twenty years have failed to provide more green area access for a diversity of socioeconomic groups in the San Juan Metropolitan region (Dinzey Flores 2006, García-Ellín 2009). A broad sector of the population in the RPW, particularly those in the lowest-income areas, has inadequate access to parks or other green public areas. Decreased accessibility is partly because of the reduction in public parks available caused by the proliferation of gated communities (Dinzey-Flores 2013), whether newly built or gated after construction, as well as the incidence of criminal activities within service areas. As a result, the poorest residents may be deterred from using parks during certain hours and from conducting activities such as physical exercise, which are associated with health benefits.

The highest-income residents exhibit the highest levels of parks and green areas accessibility, with lower crime rates in watershed service areas. This group lives mainly in private gated residential neighborhoods, where common areas are generally managed by community organizations such as homeowners associations (Suárez Carrasquillo 2011). Thus, each group can restrict access and impose regulations on appropriate conduct at these locations.

Some lower-income sectors of the population, however, seem to experience reduced accessibility and exclusion from green areas, which may partially explain why a majority of residents do not make an explicit association between green areas and the ecological benefits provided by urban neighborhood parks. Only a small group of residents indicated directly engaging in activities requiring consumption of ecological amenities in a park setting; the majority were located in the upper watershed, where green areas are more abundant, or grew food in their backyard.

Even though a majority of residents did not establish a direct link between consumption of ecological amenities in a park setting and natural areas, the most popular activities enumerated by residents could be carried out in neighborhood public parks. Urban parks still represent the closest link of watershed residents to public or common green areas, and thus, the nearest contact with a protected natural setting. However, only $60 \%$ of residents indicated feeling safe in their neighborhood park. The remaining $40 \%$ were asked what could be done to increase the feeling of safety when visiting the parks, and an overwhelming majority indicated they would like to see a presence or increased presence of law enforcement in their park. It seems that a majority of residents who currently do not feel safe understand that exclusionary measures are the preferred means to feeling comfortable using a park. Only three residents indicated green area maintenance as a solution to safety problems in their park.

The association between consumption of ecological amenities in a park setting and improved physical and mental health are a clear indication that innovative approaches are needed to improve accessibility to green areas in the lowest-income neighborhoods. Specific strategies to maximize the use and availability of green spaces should be based on more site-specific approaches that build on a thorough analysis of the neighborhood or city, its population, and available green spaces (Schipperijn et al. 2010). Residents have already suggested improvements that should be considered when formulating strategies for increasing neighborhood park visitation. Perhaps more prevalent exclusionary measures such as increased law enforcement can be replaced by innovative solutions that would attract residents and make them feel safe, such as beginning a series of communitysponsored social activities and growing vegetable community gardens at urban public parks. The idea of exploring the feasibility of vegetable community gardens at neighborhood parks is reinforced by our results showing an association between residents growing food in their backyards and consumption of ecological amenities in natural areas. Ideas such as vegetable community gardens are rather uncommon in the Río Piedras watershed, but precedents indicate that the implementation of such an activity could increase green area accessibility.

Responses to this article can be read online at: http://www.ecologyandsociety.org/issues/responses. $\mathrm{php} / 6180$

\section{Acknowledgments:}

This research was funded by the NSF award 0948507.

\section{LITERATURE CITED}

Barbosa, O., J. A. Tratalos, P. R. Armsworth, R. G. Davies, R. A. Fuller, P. Johnson, and K. J. Gaston. 2007. Who benefits from access to green space? A case study from Sheffield, UK. Landscape and Urban Planning 83(2-3):187-195. http://dx.doi.org/10.1016/j. landurbplan.2007.04.004

Bedimo-Rung, A. L., A. J. Mowen, and D. A. Cohen. 2005. The significance of parks to physical activity and public health: a conceptual model. American Journal of Preventative Medicine 28 (2S2):159-168.

Berney, R. 2010. Learning from Bogotá: how municipal experts transformed public space. Journal of Urban Design 15(4):539-558. http://dx.doi.org/10.1080/13574809.2010.502344

Boone, C. G., G. L. Buckley, J. M. Grove, and C. Sister. 2009. Parks and people: an environmental justice inquiry in Baltimore, Maryland. Annals of the Association of American Geographers 99 (4):767-787. http://dx.doi.org/10.1080/00045600903102949

Budruk, M., H. Thomas, and T. Tyrrell. 2009. Urban green spaces: a study of place attachment and environmental attitudes in India. Society \& Natural Resources 22(9):824-839. http://dx.doi. org/10.1080/08941920802628515 
Chiesura, A. 2004. The role of urban parks for the sustainable city. Landscape and Urban Planning 68(1):129-138. http://dx.doi. org/10.1016/j.landurbplan.2003.08.003

Cohen, D. A., T. Marsh, S. Williamson, K. Pitkin Derose, H. Martinez, C. Setodji, and T. L. McKenzie. 2010. Parks and physical activity: Why are some parks used more than others? Preventive Medicine 50:S9-S12. http://dx.doi.org/10.1016/j. ypmed.2009.08.020

Comber, A., C. Brunsdon, and E. Green. 2008. Using a GIS-based network analysis to determine urban greenspace accessibility for different ethnic and religious groups. Landscape and Urban Planning 86(1):103-114. http://dx.doi.org/10.1016/j.

landurbplan.2008.01.002

Dinzey Flores, Z. Z. 2006. Fighting crime, constructing segregation: crime, housing policy, and the social brands of Puerto Rican neighborhoods. Dissertation. University of Michigan, Ann Arbor, Michigan, USA.

Dinzey Flores, Z. Z. 2013. Locked in, locked out: gated communities in a Puerto Rican city. University of Pennsylvania Press, Philadelphia, Pennsylvania, USA.

Donovan, G. H., and J. P. Prestemon. 2012. The effect of trees on crime in Portland, Oregon. Environment and Behavior 44(1):3-30. http://dx.doi.org/10.1177/0013916510383238

Farber, S., R. Costanza, D. L. Childers, J. Erickson, K. Gross, M. Grove, C. S. Hopkinson, J. Kahn, S. Pincetl, A. Troy, P. Warren, and M. Wilson. 2006. Linking ecology and economics for ecosystem management. Bioscience 56(2):121-133. http://dx.doi. org/10.1641/0006-3568(2006)056[0121:LEAEFE]2.0.CO;2

García-Ellín, J. C. 2009. Gated communities and housing projects: the control of public space in San Juan. Southeastern Geographer 49(4):354-375. http://dx.doi.org/10.1353/sgo.0.0057

George, R. 2010. Visitor perceptions of crime-safety and attitudes towards risk: the case of Table Mountain National Park, Cape Town. Tourism Management 31(6):806-815. http://dx.doi. org/10.1016/j.tourman.2009.08.011

Hartley, J. 1992. The politics of pictures: the creation of the public in the age of popular media. Routledge, London, UK.

Heynen, N. 2006. Green urban political ecologies: toward a better understanding of inner-city environmental change. Environment and Planning A 38(3):499-516. http://dx.doi.org/10.1068/a37365

Heynen, N., H. A. Perkins, and P. Roy. 2006. The political ecology of uneven urban green space: the impact of political economy on race and ethnicity in producing environmental inequality in Milwaukee. Urban Affairs Review 42(1):3-25. http://dx.doi. org/10.1177/1078087406290729

Jim, C. Y., and W. Y. Chen. 2006. Impacts of urban environmental elements on residential housing prices in Guangzhou (China). Landscape and Urban Planning 78(4):422-434. http://dx.doi. org/10.1016/j.landurbplan.2005.12.003

Jim, C. Y., and X. Shan. 2013. Socioeconomic effect on perception of urban green spaces in Guangzhou, China. Cities 31:123-131. http://dx.doi.org/10.1016/j.cities.2012.06.017
Kaplan, R., and J. F. Talbot. 1988. Ethnicity and preference for natural settings: a review and recent findings. Lansdscape and Urban Planning 15(1-2):107-117. http://dx.doi.org/10.1016/0169-2046 (88)90019-9

Kuo, F. E., M. Bacaicoa, and W. C. Sullivan. 1998. Transforming inner-city landscapes: trees, sense of safety, and preference. Environment and Behavior 30(1):28-59. http://dx.doi. org/10.1177/0013916598301002

Logan, J. R. 1978. Growth, politics, and the stratification of places. American Journal of Sociology 84(2):404-416. http://dx. doi.org/10.1086/226790

MacNaghten, P., and J. Urry. 2000. Bodies in the woods. Body and Society 6(3-4):166-182. http://dx.doi.org/10.1177/1357034X$\underline{00006003009}$

Maller, C., M. Townsend, A. Pryor, P. Brown, and L. St Leger. 2006. Healthy nature healthy people: 'contact with nature' as an upstream health promotion intervention for populations. Health Promotion International 21(1):45-54. http://dx.doi.org/10.1093/ heapro/dai032

Mitchell, D. 1995. The end of public space? People's park, definitions of the public, and democracy. Annals of the Association of American Geographers 85(1):108-133.

Nicholls, S. 2001. Measuring the accessibility and equity of public parks: a case study using GIS. Managing Leisure 6(4):201-219. http://dx.doi.org/10.1080/13606710110084651

Perkins, H. A., N. Heynen, and J. Wilson. 2004. Inequitable access to urban reforestation: the impact of urban political economy on housing tenure and urban forests. Cities 21(4):291-299. http://dx. doi.org/10.1016/j.cities.2004.04.002

Peterson, R. D., and L. J. Krivo. 2010. Divergent social worlds: neighborhood crime and the racial-spatial divide. Russell Sage Foundation, New York, New York, USA.

Sanesi, G., R. Lafortezza, M. Bonnes, and G. Carrus. 2006. Comparison of two different approaches for assessing the psychological and social dimensions of green spaces. Urban Forestry \& Urban Greening 5(3):121-129. http://dx.doi. org/10.1016/j.ufug.2006.06.001

Saphores, J.-D., and W. Li. 2012. Estimating the value of urban green areas: a hedonic pricing analysis of the single family housing market in Los Angeles, CA. Landscape and Urban Planning 104 (3-4):373-387. http://dx.doi.org/10.1016/j.landurbplan.2011.11.012

Schipperijn, J., O. Ekholm, U. K. Stigsdotter, M. Toftager, P. Bentsen, F. Kamper-Jørgensen, and T. B. Randrup. 2010. Factors influencing the use of green space: results from a Danish national representative survey. Landscape and Urban Planning 95 (3):130-137. http://dx.doi.org/10.1016/j.landurbplan.2009.12.010

Suárez Carrasquillo, C. A. 2011. Gated communities and city marketing: recent trends in Guaynabo, Puerto Rico. Cities 28 (5):444-451. http://dx.doi.org/10.1016/j.cities.2011.05.009

Tabbush, P., and L. O'Brien. 2003. Health and well-being: trees, woodlands and natural spaces. Forestry Commission, Edinburgh, UK. [online] URL: http://www.forestry.gov.uk/pdf/health wellbeing. pdf/SFILE/health wellbeing.pdf. 
Troy, A., and J. M. Grove. 2008. Property values, parks, and crime: a hedonic analysis in Baltimore, MD. Landscape and Urban Planning 87(3):233-245. http://dx.doi.org/10.1016/j. landurbplan.2008.06.005

Troy, A., J. M. Grove, and J. O’Neil-Dunne. 2012. The relationship between tree canopy and crime rates across an urban-rural gradient in the greater Baltimore region. Landscape and Urban Planning 106(3):262-270. http://dx.doi.org/10.1016/j.

landurbplan.2012.03.010

Tzoulas, K., K. Korpela, S. Venn, V. Yli-Pelkonen, A. Kazmierczak, J. Niemela, and P. James. 2007. Promoting ecosystem and human health in urban areas using Green Infrastructure: a literature review. Landscape and Urban Planning 81(3):167-178. http://dx.doi.org/10.1016/j.landurbplan.2007.02.001

United States Census Bureau. 2010. American fact finder. U.S. Census Bureau, Washington, D.C., USA. [online] URL: http:// factfinder2.census.gov/.

U.S. Department of Health and Human Services. 1996. A report from the Surgeon General: physical activity and health. Centers for Disease Control and Prevention, National Center for Chronic Disease Prevention and Health Promotion, President's Council on Physical Fitness and Sports, Atlanta, Georgia, USA. [online] URL: http://www.cdc.gov/nccdphp/sgr/pdf/sgrfull.pdf.

Ward Thompson, C., P. Aspinall, S. Bell, C. Findlay, J. Wherrett, and P. Travlou. 2004. Open space and social inclusion: local woodland use in central Scotland. Forestry Commission, Edinburgh, UK. [online] URL: http://www.forestry.gov.uk/PDF/ fcrp005.pdf/\$FILE/fcrp005.pdf. 